\title{
The Limits of "Good Law": Civil Society Regulation in South Africa and Ethiopia
}

\author{
Dina Lupin* 우 \\ University of Vienna, Vienna, Austria \\ dinalupin@gmail.com
}

\begin{abstract}
At the end of apartheid, the South African government adopted laws regulating civil society that are widely seen as "good" laws: laws designed to encourage and facilitate a thriving civil society sector. In 2019 the Ethiopian government repealed the repressive, decade-old Charities and Societies Proclamation and replaced it with a much more open and permissive regulatory system, also aimed at facilitating a thriving civil society sector. This article compares South Africa's post-apartheid civil society organization (CSO) laws with Ethiopia's 2019 law, to examine the different and overlapping ways in which these regimes attempt to advance the interests of CSOs against an historical background of state oppression. In doing so, it examines what "good" regulation of CSOs constitutes in practice and finds that there are significant limits to the effectiveness of regulatory change in addressing the many, complex problems CSOs face, especially in the wake of political and legal oppression.
\end{abstract}

\section{Keywords}

Civil society, South Africa, Ethiopia, regulation

\section{INTRODUCTION}

With the end of apartheid in South Africa in 1994, laws designed to oppress and control civil society organizations (CSOs) were repealed and replaced with laws designed to facilitate a thriving civil society sector, rooted in selfregulation. More than 20 years later and 5,000 kilometres away, in 2019 the Ethiopian government also repealed its repressive civil society law and replaced it with a much more permissive regulatory system, rooted, at least in part, in self-regulation.

* Postdoctoral researcher, Department of Philosophy, University of Vienna. The author thanks Jonathan Verschuuren, Desta Gidey, Nicky Broeckhoven and Kelemework Tafere, as well as the anonymous reviewers, for feedback on this article. This research was funded by the Netherlands Organisation for Scientific Research (NWO/WOTRO) under its Science for Global Development Programme: Supporting the Political Role of Civil Society Organisations for Inclusive Development (grant no W08.311.102). 
A significant growth in the number of states using legislative measures to limit the work and funding of $\operatorname{CSOs}^{1}$ in the past decade has effectively demonstrated the extent to which the sector is influenced by legal frameworks ${ }^{2}$ and how vulnerable civic action is to state suppression, subversion and control. ${ }^{3}$ While scholars and activists have highlighted the many examples of "bad" or "unfavourable" civil society law, determining what constitutes "good" or "favourable" civil society law can be much more difficult. This is in part because the question of whether or not law is favourable depends on how it is implemented and to whom it is applied. ${ }^{4}$ This problem is exacerbated by the fact that the idea of a CSO encompasses a wide range of entities, which may be affected in very different ways by the law. ${ }^{5}$ Nevertheless, states sometimes adopt legal measures that are seen as "good" civil society law. That is, law that: facilitates the establishment of CSOs; enables their fundraising activities; allows them to pursue their chosen activities and agendas, including through advocacy and other political engagement; and advances good CSO governance, including through self-regulation. ${ }^{6}$ Both South Africa's 1997

1 This article does not examine this global trend, but the phenomenon is well documented. See "Defending civil society" (2nd ed, June 2012, International Center for Not-for-Profit Law (ICNL) and World Movement for Democracy Secretariat at the National Endowment for Democracy) at 14; A Buyse "Squeezing civic space: Restrictions on civil society organizations and the linkages with human rights" (2018) 22 The International Journal of Human Rights 966; S Brechenmacher "Civil society under assault: Repression and responses in Russia, Egypt, and Ethiopia" (2017, Carnegie Endowment for International Peace); MT Maru Shrinking Civil Society Space in the Horn of Africa: The Legal Context (2017, PAX, Al Khatim Adlan Center for Enlightenment and Human Development, and Horn of Africa Civil Society Forum), available at: <http:// www.kacesudan.org/wp-content/uploads/2017/09/PAX_REPORT_KACE_FINAL_digi_ single_page.pdf> (last accessed 14 December 2021); C van der Borgh and C Terwindt "Shrinking operational space of NGOs: A framework of analysis" (2012) 22 Development in Practice 1065. For an overview of the legal and regulatory measures used to curtail international funding, see D Rutzen "Civil society under assault" (2015) 4/26 Journal of Democracy 28 at 30-31.

2 S Toepler and L Salamon "The influence of the legal environment on the development of the nonprofit sector" (Center for Civil Society Studies working paper series, 2000).

3 N Hossain et al "What does closing civic space mean for development? A literature review and conceptual framework" (IDS working paper, 2018) at 15.

4 As Toepler and Salamon have pointed out, what might appear to be neutral or even encouraging regulations can be used both to facilitate and undermine CSOs. For example, "public reporting requirements, which can give the public more confidence that nonprofit organizations are not abusing their trust, ... [come] at the expense of discouraging potential nonprofit entrepreneurs from forming nonprofit agencies because of the reporting burdens involved": Toepler and Salamon "The influence", above at note 2 at 4.

5 Buyse "Squeezing civic space" above at note 1 at 968-69; $\mathrm{H}$ Anheier "Private voluntary organizations and the Third World: The case of Africa" in $\mathrm{H}$ Anheier and W Seibel (eds) The Third Sector: Comparative Studies of Nonprofit Organizations (1990, De Gruyter) 361 at 368 .

6 A number of guides and other resources make recommendations for how states should regulate civil society. The four considerations listed here all come from the "Checklist for 
Nonprofit Organisations Act and Ethiopia's 2019 Organizations of Civil Societies Proclamation have been described as examples of "good" law in this sense, aimed at facilitating and enabling the civil society sector in each country. ${ }^{7}$

This article compares South Africa's post-apartheid CSO laws with Ethiopia's 2019 law in order to examine the different and overlapping ways in which these regimes attempt to advance the interests of CSOs against an historical background of state oppression. It compares the different approaches to CSO regulation that these countries adopt and finds that more than regulatory change is needed if these countries are going to address the many, complex problems CSOs face, especially in the wake of political and legal repression.

The article begins with a brief discussion of the methodology used in the research, followed by an introduction and background to each of the countries and the conditions in which regulatory change has taken place. It then examines four comparative aspects of South Africa's and Ethiopia's laws: the forms of CSOs for which the law provides; civil society fundraising; selfregulation; and state-CSO relationships. After 20 years of operating in a permissive regulatory environment, South African CSOs face enormous problems in all these areas and the experience of South African CSOs offers some useful insights into the limits of "good" law. In Ethiopia, on the other hand, CSOs have started working in a more permissive regulatory environment, but are still controlled and overseen by the same institutions and people previously charged with their control and repression.

South African experiences offer lessons for Ethiopia about the limits of "good law". However, Ethiopia's unique history and the unusual circumstances of the ongoing political changes in that country suggest some possible obstacles to realizing the promise of its new law. The article concludes by

contd

CSO laws" developed by the ICNL (2006). The aim in this article is not to add to existing checklists, guidelines or recommendations, but rather to look at how laws that are seen to be good laws operate in practice. See also D Rutzen and D Moore The Role of Legal Reform in Supporting Civil Society: An Introductory Primer (2009, ICNL and UN Development Programme); L Irish, R Kushen and KW Simon Guidelines for Laws Affecting Civic Organizations (2004, Open Society Institute), available at: <https://www. opensocietyfoundations.org/publications/guidelines-laws-affecting-civic-organizations> (last accessed 14 December 2021); L Salamon and S Flaherty "Nonprofit law: Ten issues in search of resolution" (working papers of the Johns Hopkins Comparative Nonprofit Sector Project, 1996).

7 Comments on Ethiopia's Organizations of Civil Societies Proclamation have been positive but reservations have been raised about particular provisions. See, for example, "Ethiopia: UN experts commend civil society law reforms, but concerns remain" (April 2019, UN High Commissioner for Human Rights), available at: <https://www.ohchr. org/en/NewsEvents/Pages/DisplayNews.aspx?NewsID=24443\&LangID=E > (last accessed 14 December 2021); and "Ethiopia: Civil society proclamation advances essential freedoms" (Freedom House press release, 8 February 2019), available at: <https://freedo mhouse.org/article/ethiopia-civil-society-proclamation-advances-essential-freedoms> (last accessed 14 December 2021). 
looking at the role and limits of law in advancing civil society after periods of oppression.

\section{METHODOLOGY AND TERMINOLOGY}

This article draws on a document and literature study on Ethiopian and South African civil society law. In addition, the findings on Ethiopia are drawn from 28 interviews with key CSO representatives as well as government officials working for the Charities and Societies Agency (the Agency), trade unions and academics, conducted before the 2019 law had been finalized. The article also draws on focus group discussions with an additional 52 CSO representatives, academics and government officials in May 2019, after the new law had come into effect. ${ }^{8}$

The article is comparative, bringing together two very different legal systems. There are a number of historical, political and legal factors that make a direct comparison between South African and Ethiopian law challenging. South Africa's mixed legal system reflects its colonial past. It is a constitutional system that brings together civil law, African customary law, Roman-Dutch law and English common law. Ethiopia, on the other hand, has a primarily civil system with legislative power resting in the hands of both the federal government and the nine ethnically based regional states. ${ }^{9}$ While these systems are very different from each other, both countries primarily regulate CSOs through national legislation ${ }^{10}$ and the creation of administrative agencies tasked with implementing that law. ${ }^{11}$ Comparing these regulatory instruments allows for a clear insight into the similarities and differences of the two countries' regulatory approaches. Understanding the law of each country, however, requires a sensitivity to the legal and cultural context of those laws and their impacts on the interpretation and application of the legislation in each case. While the article aims to compare the law in each country, it attempts to do so by looking at the law in context and in practice in each jurisdiction. ${ }^{12}$

Throughout this article, the term "CSO" is used to encompass the range of organizations that are regulated under South African and Ethiopian law.

8 The interviews were conducted by researchers at the University of Mekelle Law School and Tilburg University Law School.

9 For more on ethnic federalism in Ethiopia, see J Abbink "Ethnic-based federalism and ethnicity in Ethiopia: Reassessing the experiment after 20 years" (2011) 5 Journal of Eastern African Studies 596.

10 The exceptions to this are voluntary associations under South African law and, in Ethiopia, CSOs governed by the laws of the regional state in which they exclusively operate.

11 Ethiopian legislative drafters looked to South Africa as an example in drafting both the 2009 and 2019 laws.

12 In this sense, the article adopts the comparative "law-in-context" method. For more on this approach and its relationship to other comparative methods, see M Van Hoecke "Methodology of comparative legal research" (2015) Law and Method 1. 
While there are many different kinds of CSOs, they are often roughly classed together as voluntary and independent organizations that operate outside the family, state and market, and that work to advance shared interests. Within this group are multi-national institutions, religious groups, non-profit companies, sports associations, protest movements, community savings schemes and many others. These different organizations are differently established, regulated and funded, and have divergent priorities and interests in relation to all of these aspects. The regulatory needs and interests of these organizations vary significantly, as do their interests in external funding. In this article, the focus is on formal or semi-formal organizations, often subject to regulation and which usually seek funding to undertake their activities. This includes organizations engaged in development work (often referred to as non-governmental organizations or NGOs) but might include faith-based groups, research networks, trade unions or professional associations, among others that do not necessarily self-identify as NGOs. ${ }^{13}$

\section{BACKGROUND}

\section{South Africa: Civil society under and after apartheid}

Under the apartheid state, civil society operated under conditions of extreme state control, but nevertheless played a critical role in the anti-apartheid resistance movement. ${ }^{14}$ The apartheid state broadly categorized CSOs into two key groups: those that were sympathetic with and supportive of the state (such as the Broederbond and the Dutch Reform Church) and those that were critical. ${ }^{15}$ This division was also racial: white-run CSOs faced few of the obstacles that black organizations faced. ${ }^{16}$ As a result, the regulation of CSOs under apartheid allowed the state to control CSO activities and fundraising to advance the interests of pro-apartheid, white CSOs and to hamper the funding and activities of organizations run by black South Africans and those that opposed the state.

The state actively and aggressively suppressed CSOs that opposed apartheid. ${ }^{17}$ This harassment and suppression took different forms. First, the state sought to discourage and prevent CSOs through legislative and regulatory mechanisms that limited their ability to raise funds (under the 1978 Fundraising Act) and by banning meetings, gatherings, protest action and other collective action. Secondly, the state engaged in direct violence against CSO members and, particularly under the state of emergency in the late 1980s, through mass arrests. ${ }^{18}$

\footnotetext{
13 The author thanks an anonymous reviewer for pushing for this clarification.

14 A Habib State of the Nation: South Africa, 2003-2004 (2003, HSRC Press) at 230.

15 Ibid.

16 AO Okoye "The role of law in the development of the nonprofit sector in Nigeria and South Africa" (PhD thesis, University of Cape Town, 2006) at 110; Habib, ibid.

17 Okoye, id at 108.

18 Habib State of the Nation, above at note 14 at 231.
} 
Limited access to funding and constant state harassment meant that antiapartheid organizations struggled to claim meaningful space in the 1970s. With the liberalization of the political system in the early 1980s, however, antiapartheid CSOs grew and multiplied. Black unions were legalized and other CSOs were able to re-emerge in the new, more permissive political landscape. However, the goal of the apartheid state was liberalization to co-opt some elements of black civil society and community, while continuing to marginalize and suppress others. ${ }^{19}$ Despite this suppression and because of the positive role CSOs played in the anti-apartheid struggle, they retained a large degree of popular legitimacy during and after the apartheid era. ${ }^{20} \mathrm{~A}$ crucial aspect of the emergence of a strong anti-apartheid civil society was the new availability of international funding as a result of international media coverage of the 1976 student uprising. As a result of both political opportunity and resource mobility, civil society grew significantly in the last decade of apartheid. ${ }^{21}$

After 1994, South Africa's new democratic government sought to create an enabling legal and political environment for CSOs. Repressive apartheid laws were repealed and a raft of new legislation was passed to recognize CSOs and their role in the new democratic society. ${ }^{22}$ The new constitution entrenched rights to freedom of association, speech and expression, ${ }^{23}$ and gave CSOs locus standi to bring public interest litigation before the courts. $^{24}$

Under South Africa's mixed legal system, CSOs can be established in a number of ways, although the primary legislation governing the sector is the Nonprofit Organisations Act (NPO Act), ${ }^{25}$ which seeks to encourage selfregulation of CSOs and good CSO-state relations. The NPO Act states that its purpose is to "provide for an environment in which nonprofit organisations can flourish". ${ }^{26}$

19 S Hurt "Civil or uncivil society? The internal governance and external regulation of civil society and the impact of constitutionalism on civic space in South Africa" (paper presented at the Twenty Years of South African Constitutionalism: Constitutional Rights, Judicial Independence and the Transition to Democracy conference, New York Law School, New York, November 2014) at 6.

20 Habib State of the Nation, above at note 14 at 231.

21 Id at 232.

22 It should be noted that this transition was not completely smooth and CSOs faced a variety of challenges during the period of transition from apartheid to democracy. See Okoye "The role of law", above at note 16 at 113-14.

23 Constitution of the Republic of South Africa Act 108 of 1996, chap 2.

24 Id, art 38.

25 Act 71 of 1997.

26 Id, sec 1(1)(x). Id, preamble defines "nonprofit organisation" as "a trust, company or other association of persons (a) established for a public purpose; and (b) the income and property of which are not distributable to its members or office-bearers except as reasonable compensation for services rendered". 


\section{Ethiopia: Civil society under monarchy, military rule and ethnic federalism}

Until the early 1990s, modern CSOs played a fairly limited role in Ethiopia. ${ }^{27}$ Under monarchical and then communist rule, independent, politically active and foreign-funded CSOs were not permitted to operate in the country. Community-based organizations (CBOs) were allowed to exist and certain kinds of CBOs and community self-help organizations have a long history in the country. After the military Derg regime removed Emperor Hallie Selassie and ended monarchical rule in the country, many CBOs were either co-opted or marginalized. ${ }^{28}$ It was only in the wake of devastating famines that the Derg regime agreed to accept international organizations and foreign aid assistance. ${ }^{29}$ These organizations worked primarily on relief and humanitarian services. ${ }^{30}$

After the overthrow of the Derg regime and the coming to power of the Ethiopian Peoples' Revolutionary Democratic Party (EPRDF) in 1990, CSOs enjoyed a period of relative freedom and the number of local and international CSOs in the country began to grow. The new government did not immediately adopt a comprehensive law on CSOs and these organizations continued to be governed by the 1960 Civil Code of Ethiopia and the Association Registration Regulation. ${ }^{31}$ In this new political era, in which CSOs faced few regulatory constraints, they not only worked on service provision and relief work, but increasingly began working on advocacy and playing a greater political role.

CSOs played a significant and active role in the build-up to the 2005 elections, ${ }^{32}$ engaging in voter education, hosting debates and dialogue between political representatives, and deploying observers to voting stations. ${ }^{33}$ In the build-up to the elections, opposition parties attracted unprecedented support. When the EPRDF won with a significant majority, opposition parties contested the results. This conflict led to waves of protest and violence over several

27 T Wada "The regulatory framework for civil society organizations in Ethiopia" in T Assefa and B Zewde (eds) Civil Society at the Crossroads: Challenges and Prospects in Ethiopia (2008, Forum for Social Studies) 159 at 161 . See also N Broeckhoven et al "CSOs in sustainable development in Ethiopia: Past practices and new trajectories” (2020) 1 African Journal of Legal Studies 1.

28 Brechenmacher "Civil society under assault", above at note 1 at 66.

29 K Dupuy, J Ron and A Prakash "Who survived? Ethiopia's regulatory crackdown on foreign-funded NGOs" (2015) 22 Review of International Political Economy 419 at 424.

30 D Rahmato "Civil society organisations in Ethiopia" in B Zewde and S Pausewang (eds) Ethiopia: The Challenge of Democracy from Below (2002, Elanders Gotab) 103 at 106.

31 No 321/1966. See "Explanation of the FDRE Ministry of Justice on charities and societies draft legislation" (September 2008) at 5.

32 W Teshome-Bahiru "Civil society and democratization in Africa: The role of the civil society in the 2005 election in Ethiopia" (2009) 3 International Journal of Humanities and Social Sciences 1598.

33 T Roberts "Closing civic space and inclusive development in Ethiopia" (IDS working paper 15, 2019); Brechenmacher "Civil society under assault", above at note 1 at 67. 
months. ${ }^{34}$ The EPRDF blamed CSOs for their role in the election process ${ }^{35}$ and this is seen as one of the key triggers for the government's decision to adopt the Charities and Societies Proclamation in 2009 (CSP), ${ }^{36}$ legislation that gave the state far greater control over CSO activities and funding. ${ }^{37}$

Under the CSP, CSOs were subject to close regulatory and administrative control of their activities, funding and assets. The CSP stipulated that foreign CSOs and those organizations that received more than 10 per cent of their funding from foreign sources could not engage in a wide range of activities, including advocacy and work on human rights and democracy. ${ }^{38}$ These organizations were almost exclusively limited to service delivery and relief work. CSOs that wished to work on matters related to human rights, democracy and governance had to obtain more than 90 per cent of their funds from domestic sources.

The CSP sought to transform civil society into a service sector. ${ }^{39}$ One of the ways it did this was by regulating not only the source of funds but also the use of funds by CSOs. The law required CSOs to allocate 70 per cent of their budget to operational costs and only 30 per cent to administrative activities. ${ }^{40}$ This 70:30 rule was meant to ensure that the bulk of CSO funding benefited those in need. However, the CSP defined administrative activities so broadly that it included a wide range of costs that would normally have been considered part of the cost of implementing a programme. ${ }^{41}$ As a result, organizations were unable to train staff, commission studies, network or participate in other training and research activities.

CSOs were also subject to mandatory registration and reporting requirements, ${ }^{42}$ the administration of which was overseen by the Agency, a government body that was viewed by many CSOs as incompetent, under-resourced and generally antithetical to the interests of $\mathrm{CSOs}^{43}$ As a result of the

34 L Arriola "Ethiopia" in J Dizard, C Walker and V Tucker (eds) Countries at the Crossroads 2011: An Analysis of Democratic Governance (2012, Rowman \& Littlefield) 235 at 236. See also J Abbink "Discomfiture of democracy? The 2005 election crisis in Ethiopia and its aftermath" (2006) 105 African Affairs 173 at 176.

35 Roberts "Closing civic space", above at note 32 at 15.

36 Proc no 621/2009.The CSP refers to charities and societies. For the purposes of this article, little turns on this distinction and both are included under the term "CSOs".

37 Brechenmacher "Civil society under assault", above at note 1.

38 CSP, art 14(5).

39 D Townsend and N Broeckhoven "Rights, development and sustainability: The costs of human rights in Ethiopia" in J Wouters (ed) Can We Still Afford Human Rights? Critical Reflections at the Occasion of the 70th Birthday of the UDHR (2021, Edward Elgar Publishing) 270.

40 CSP, art 88.

41 Interview with CSO employee, Ethiopia, 15 August 2018.

42 CSP, art 64.

43 Interview with CSO employee, The Netherlands, 20 September 2018; interview with CSO employee, Ethiopia, 3 August 2018; interview with CSO employee, Ethiopia, 15 August 2018. 
repressive law, funding restrictions and the Agency's broad administrative powers, many CSOs shut down ${ }^{44}$ or radically reduced their operations. ${ }^{45}$

In 2018, starting with the resignation of Ethiopia's Prime Minister Hailemariam Desalegn, Ethiopia underwent a series of drastic and fast-paced political changes at both the international and domestic level. The prime minister's resignation came in the wake of mass protests in Oromia and Amhara. ${ }^{46}$ The state's response to the protests was brutal, resulting in deaths and mass arrests under extended states of emergency. ${ }^{47}$ The protests, coupled with growing disunity within parts of the ruling party, ${ }^{48}$ created the crisis conditions necessary for a political shift and the appointment of new Prime Minister Abiy Ahmed. While the governing party, the EPRDF, has remained in power, the changes brought about by Abiy in his first few months in office were far reaching and have been referred to as Ethiopia's "quiet revolution". ${ }^{49}$ The rise of Abiy, and the many political changes that were quickly introduced after his inauguration, came as a surprise, even to those within the EPRDF itself. $^{50}$ In June 2018, Abiy announced his intention to repeal repressive laws, including laws on civil society, terrorism and mass media. After some months of revision and consultation by a law review committee, a new civil

44 Interview with civil society employee, Ethiopia, 14 August 2018. For example, the German political foundation, Heinrich Böll Stiftung, was forced to close its offices in Addis Ababa: "Closure of the Heinrich Böll Foundation office in Ethiopia" (November 2012, Heinrich Böll Stiftung), available at: <https://www.boell.de/en/intlpolitics/africaclosure-heinrich-boell-foundation-office-ethiopia-background-16060.html> (last accessed 14 December 2021). See also Dupuy, Ron and Prakash “Who survived?", above at note 29 at 431 .

45 See the discussion of the impacts of civil society law in Ethiopia in Y Gebre "Reality checks: The state of civil society organizations in Ethiopia” (2016) 20 African Sociological Review 2; S Yeshanew "CSO law in Ethiopia: Considering its constraints and consequences” (2012) 8 Journal of Civil Society 369. Interview with CSO employee, Ethiopia, 2 August 2018.

46 J Fisher and MT Gebrewahd “'Game over'? Abiy Ahmed, the Tigrayan People's Liberation Front and Ethiopia's political crisis" (2018) 118 African Affairs 194 at 200; "US: Stand up for Ethiopians as government stifles protests, jails journalists" (Human Rights Watch statement on Ethiopia to US Congress, 9 March 2017), available at: <https:/www.hrw. org/news/2017/03/09/us-stand-ethiopians-government-stifles-protests-jails-journalists> (last accessed 14 December 2021); “\#OromoProtests: 100 days of public protests” (2016, Ethiopia Human Rights Project); E Chala "Ethiopia scraps Addis Ababa 'master plan' after protests kill 140" (14 January 2016) The Guardian.

47 “\#OromoProtests”, ibid.

48 Fisher and Gebrewahd “"Game over'?”, above at note 46 at 202.

49 Y Woldemariam "Ethiopia's quiet revolution: From revolutionary developmentalism to neoliberal reform" (August 2018) Review of African Political Economy, available at: <http:// roape.net/2018/08/07/ethiopias-quiet-revolution-from-revolutionary-developmentalismto-neoliberal-reform/> (last accessed 14 December 2021).

50 Fisher and Gebrewahd “'Game over'?”, above at note 46 at 194. The authors argue, however, that Ethiopia's current political dynamics have evolved from long-term phenomena and are not merely the product of Abiy's leadership. 
society law was drafted and, in March 2019, the Ethiopian Parliament adopted the Organizations of Civil Societies Proclamation 1113 (CSOP). ${ }^{51}$

\section{FORMS OF CSO, REGISTRATION AND ADMINISTRATION}

\section{Forms of CSO}

As discussed, the range of organizations that might be classified as a CSO is vast, extending from small, grassroots organizations to multinational NGOs. ${ }^{52}$ Regulating such a wide range of organizations, and organizational needs, is no easy task. What is more, the legal recognition and classification of CSOs into different forms can serve to control rather than facilitate civil society. Historically in both South Africa and Ethiopia, CSOs were classed in ways designed to ensure that the state maintained control over CSO work and funding. ${ }^{33}$

Today, South Africa recognizes a number of different kinds of CSOs with a variety of needs, capacities and budgets. ${ }^{54}$ The simplest form of CSO is the voluntary association under common law, which is established simply by agreement between at least three people. There is no legal obligation for this agreement to be in writing or for the association to draw up a written constitution. There is no limitation on who may found such an organization. Founders can include individuals, legal entities (such as companies) and foreign nationals. There are no sanctions or penalties or special regulatory requirements distinguishing between these possible founders.

This structure has a number of important advantages. No resources or external expertise are required to establish a voluntary association. There are no reporting obligations, so voluntary associations can cost almost nothing to run and are (at least somewhat) immune to government interference or even knowledge of their activities. ${ }^{55}$ As a result, this is an accessible means for organization and coordination without the burden or costs of registration or reporting. There are two possible disadvantages to the voluntary association model. First, voluntary associations are not able to access various funding sources that require formal registration. Those associations that require external funding to finance their operations may, as a result, face significant obstacles in their efforts to attract funding. ${ }^{56}$ Secondly, these organizations are

51 (12 March 2019) Federal Gazette.

52 Buyse "Squeezing civic space", above at note 1 at 968; Salamon and Flaherty "Nonprofit law", above at note 6 at 5-7.

53 van der Borgh and Terwindt "Shrinking operational space", above at note 1 at 1074 .

54 NPO Act, "Definitions".

55 M Honey "Legal structures commonly used by nonprofit organisations", available at: <https://www.etu.org.za/toolbox/docs/building/lrc.html> (last accessed 14 December 2021).

56 Many associations will not require external funding. The point remains that organizations may choose not to register but do not have all the options and privileges that registered organizations enjoy. This undermines the freedom to choose to operate as a voluntary association. The author thanks a blind reviewer for pushing for clarification on this point. 
difficult to monitor or hold to account. Neither the state nor civil society support organizations may be aware of the existence of a voluntary association and, with no obligation on voluntary associations to report on their activities or funds, it may be impossible to know whether they are actually acting in the interests of their constituents.

CSOs can, alternatively, choose to register under the NPO Act. Registration is free ${ }^{57}$ but brings with it various demands with respect to written documentation ${ }^{58}$ and annual financial and other reporting requirements, compliance with which can be expensive or time consuming. However, registration enables CSOs that require external funding to access various funding sources, including government funding. Most significantly, a registered CSO can apply for funds from government funding agencies such as the National Lottery Fund, which distributes earnings from the National Lottery (discussed in greater detail below). Depending on the needs and nature of the organization, it can also be established as a trust or as a non-profit company. ${ }^{59}$ From a regulation and oversight point of view, the most demanding of these options is the company, which is governed by the Companies Act. ${ }^{60}$ The Companies Act spells out the duties of directors and rights of members, and includes detailed requirements with respect to founding documents, who can act as a director, and the accessibility of information to members and the wider public. Between the voluntary association and the non-profit company, South African law accommodates a wide variety of CSOs, CSO needs and capacities.

The recognition of different types of CSO can both advance and hinder the interests of CSOs. While categorizing CSOs to ensure greater state control is problematic (as was the case under the old Ethiopian CSP), ensuring flexibility in the law to allow CSOs to choose their own form and structure allows for the establishment of a variety of organizations and for different CSO needs to be met. It is thus interesting to note that Ethiopia's CSOP does something entirely different to both the old CSP and the South African model.

Under both Ethiopia's old and new laws, certain classes of CBOs are excluded from regulation. For example, informal, community-based financial organizations such as iddirs and iqqubs have been used for generations by groups seeking to set up systems for insurance and savings. ${ }^{61}$ These entities

57 NPO Act, sec 12.

58 Id, sec 13.

59 Id, sec $1(1)(x)$.

60 The Companies Act 71 of 2008 provides for the creation and registration of both profitmaking and non-profit companies. Non-profit companies are incorporated for a "public benefit purpose" and may not distribute any income to their members or directors except as reasonable compensation for work performed.

61 JA Clark "Civil society, NGOs, and development in Ethiopia: A snapshot view" (World Bank working paper no 21646, June 2000), available at: <http://documents.worldbank. org/curated/en/611131468773954100/Civil-society-NGOs-and-development-in-Ethiopiaa-snapshot-view> (last accessed 14 December 2021). South African communities have established similar financial arrangements, called stokvels. 
are largely unregulated, subject to neither the demands nor the advantages of civil society laws. Iddirs and iqqubs aside, all CSOs subject to federal law in Ethiopia ${ }^{62}$ must be registered and are subject to annual reporting requirements, regardless of their size or the extent of their funding. The South African non-registered, voluntary association, with separate legal personality and standing, has no equivalent in Ethiopian law. Under the CSOP, all new CSOs must register with the Agency and existing CSOs are required to re-register to continue their operations. ${ }^{63}$

While the issue of registration might appear, at first glance, to be merely a bureaucratic concern, registration can play a critical role in both enabling and protecting CSOs, and in problematic state control and oversight of CSOs. Registration can bestow legitimacy on organizations, recognizing their legal standing, facilitating their funding endeavours and improving their standing with government bodies and the public. ${ }^{64}$ On the other hand, states can use registration requirements to control what kind of organizations are allowed to operate in a country, and to hinder the activities of CSOs through overly burdensome fees and reporting requirements. ${ }^{65}$ In both South Africa and Ethiopia, it is also apparent that registration requirements can give extraordinary powers to government administrators who control registration processes. As a result, the issue of registration is of crucial importance, and it is to this issue that this article now turns.

\section{Registration and administrative authorities: The Agency and the Directorate}

Under both South African and Ethiopian law, the right to form a CSO is seen as a component of the right to freedom of association. ${ }^{66}$ This is a right entrenched in the constitutions of both countries ${ }^{67}$ and in international human rights instruments to which both countries are parties. As a result, both countries are committed not to put unnecessary and unjust barriers in the way of free association.

As discussed, enabling CSOs to register with the state or with recognized registration authorities can play a role in advancing CSO interests. It may also ensure a greater degree of accountability and transparency in the civil society sector, where registration is accompanied by reporting requirements or obligations on CSOs to make information available to their constituents.

62 The states may pass their own regulations for local CSOs operating exclusively within the boundaries of their state: CSOP, art 3.

63 Id, art 7(57).

64 Buyse "Squeezing civic space", above at note 1 at 970; Irish, Kushen and Simon Guidelines for Laws, above at note 6 at 25.

65 Toepler and Salamon "The influence", above at note 2 at 4 .

66 Preambles to the CSOP and the NPO Act.

67 Constitution of the Republic of South Africa 1996, sec 18; Constitution of the Federal Democratic Republic of Ethiopia 1995, art 31. 
Given the significant funds that are mobilized by some parts of the CSO sector and the role that CSOs can play in rolling out social services and in engaging in political activities, registration and reporting can be essential to ensuring a well-run, responsible and accessible sector. ${ }^{68}$

However, the requirement that all civil society organizations must be registered, with the accompanying registration fees and costly reporting requirements, may amount to an unjust barrier to freedom of association. ${ }^{69}$ Under the CSOP, not only are new CSOs required to register but all existing CSOs are also required to reregister. ${ }^{70}$

Making registration compulsory (or even necessary for obtaining access to funding sources, as is the case in South Africa) means that the entities established to administer the registration of CSOs can become very powerful and influential. In both Ethiopia and South Africa, corruption, incompetence and bureaucratic inefficiency in the government entities tasked with administering CSOs have constituted significant barriers to the freedoms and functioning of many organizations.

While Ethiopia's CSOP is relatively new, the entity tasked with overseeing CSO registration and related administration is the same agency that was established under the old CSP. Under the CSP, the Agency was responsible for the registration of CSOs and had the power to license, register and supervise CSOs, ${ }^{71}$ as well as to take administrative measures, including suspending or cancelling their registration. ${ }^{72}$ The discretion given to the Agency with regard to these actions was extremely wide and was final, with no possibility for Ethiopian resident or foreign organizations to appeal to the court. $^{73}$

Many CSOs believed that Agency staff used and abused their discretion to police, delay and interfere with the work of CSOs. CSOs reported that the Agency was unduly and excessively interventionist, slow and corrupt, lacked necessary expertise and generally displayed a negative attitude towards CSOs. As a result, the Agency's interpretation and application made the restrictive CSP even more repressive. Significantly, under Ethiopia's new CSOP, the same Agency (renamed the Civil Society Organization Agency), staffed by the same officials, still has the power to register and administer CSOs in Ethiopia. ${ }^{74}$

The CSOP, however, has introduced a number of important changes to the scope and range of the Agency's powers. While the Agency is still responsible

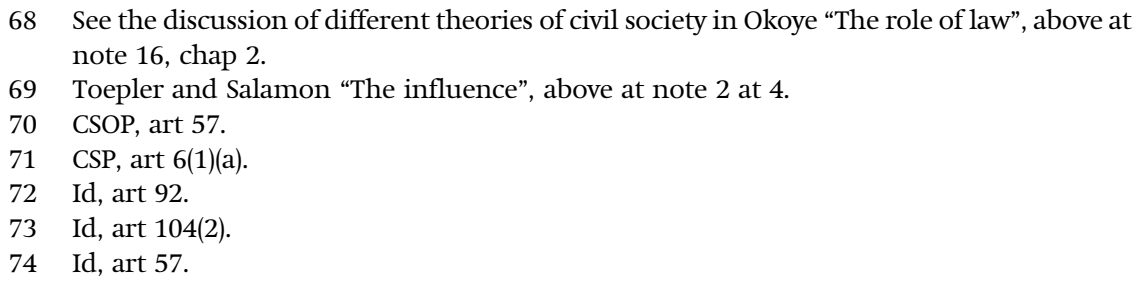


for registering CSOs, the circumstances in which it can deny registration are limited and it no longer has a broad discretion to decide whether an organization should be allowed to come into existence. ${ }^{75}$ Agency officials no longer have the power to suspend or deregister organizations and a process has been established for suspension by the director-general in limited circumstances. ${ }^{76}$ In addition, the Agency is now tasked with a range of roles that are meant to facilitate and encourage the work of CSOs and to improve the relationship between the state and CSOs. ${ }^{77}$ The Agency is also responsible for receiving annual reports on CSOs' activities and finances, and ensuring that organizations are operating in accordance with their stated aims and in accordance with the requirements of the law.

While the Agency's powers have been limited and it is now established to fulfil a vital bureaucratic function, the fact that the same body and personnel responsible for radically limiting the freedom and operations of CSOs have now been tasked with facilitating and promoting CSOs brings enormous challenges. For one, people working in the CSO sector have developed years of mistrust of Agency officials as a result of both their incompetence and corruption, and also what CSOs perceive as the Agency's antagonistic view of civil society. Civil society perceptions of the Agency aside, it is also far from clear that the Agency has the competency or ability to fulfil its new mandate. This means that the requirement that all CSOs register and report to the Agency under the CSOP still makes CSOs vulnerable to the control, oversight and incompetence of the state and (possibly antagonistic) Agency officials.

Whether Ethiopia's Agency will be able to transform itself and fulfil its new mandate under the CSOP remains to be seen, but the South African experience does not offer a promising example. In South Africa, entities established for the purpose of promoting and assisting CSOs have instead obstructed their right to freedom of association and undermined the functioning and flourishing of the civil society sector. Under South African law, the NPO Directorate (the Directorate) was established to administer and register those organizations seeking registration under the NPO Act. ${ }^{78}$ The act provides that the Directorate has two months to decide on an application and either register the organization or ask for further information. ${ }^{79}$ While the NPO Act is meant to facilitate NPO establishment and operations, in practice registration processes are slow and inaccessible and, similarly to Ethiopia under the CSP, Directorate staff hold significant power to deregister NPOs, with potentially devastating consequences. In January 2013, for example, the Directorate deregistered 36,488 NPOs of the approximately 100,000 registered at the time. It

75 CSOP, art 59.

76 Id, art 70 .

77 Id, art 5 (Objectives of the Agency).

78 NPO Act, secs 4 and 5.

79 This is twice the length of time within which an application must be processed under Ethiopian law: under CSOP, art 68(1), the Agency only has 30 days to register an applicant. 
claimed that this was due to the failure of these organizations to submit annual reports. This was contested by NPOs that claimed their documentation was in order. ${ }^{80}$ NPOs are obliged to submit annual audited financial statements and narrative reports to the Directorate, failing which they can be unilaterally deregistered. CIVICUS has found that, "given the lack of transparency and safeguards against excessive state discretion, the deregistration process remains susceptible to state abuse and manipulation to harass or sanction outspoken and independent NGOs". 81

South Africa's Directorate is woefully under-funded and lacks the resources for dealing with the high number of organizations applying for registration and submitting annual reports. In a 2016 report, CIVICUS found that the registration process was opaque and a process that "privileges NGOs in the capital [where the Directorate is housed] and its surrounding cities which have direct access to the NPO directorate". ${ }^{82}$ Organizations have reported experiencing extensive delays in their registration, up to 18 months long. ${ }^{83}$ The South African experience suggests that well-intended regulatory provisions can be just as damaging as oppressive regulation when left in the hands of incompetent, corrupt or under-resourced state entities. ${ }^{84}$

Registration can play a valuable role in assisting some CSOs. Formalizing organizations in this way can provide them with legal protection and give them greater access to external funding. Registration can also be a mechanism through which the state encourages good governance and transparency, through financial and activity reporting obligations. On the other hand, as both the South African and Ethiopian cases demonstrate, a requirement that CSOs register can also be a means by which the state exerts unnecessary control over CSOs through monitoring their activities and preventing the establishment of CSOs that are critical of the state. While adopting laws that limit the discretion of state agents is essential to avoid abuse of this requirement, as Ethiopia has done in the CSOP, the lesson from South Africa is that a poorly run or corrupt government agency can have a far-reaching and detrimental impact on CSOs, even under a progressive regulatory framework.

80 L Stuart "The South African nonprofit sector: Struggling to survive, needing to thrive" (April 2013), available at: <https://www.polity.org.za/print-version/the-south-africannon-profit-sector-struggling-to-survive-needing-to-thrive-2013-04-03> (last accessed 14 December 2021).

81 "Joint submission to the UN universal periodic review: 27th session of the UPR Working Group" (2016, World Alliance for Citizen Participation and Human Rights Institute of South Africa), para 2.5.

82 Id, para 2.3

83 Ibid.

84 The UN has noted that the arbitrary application of law can be just as problematic as "bad" law. See UN Human Rights Council res 24/21 "Civil society space: Creating and maintaining, in law and in practice, a safe and enabling environment" (23 September 2013), UN doc A/HRC/24/L.24. 


\section{FUNDRAISING}

Both South Africa's NPO Act and Ethiopia's CSOP create open and permissive funding environments for CSOs that depend on external funding, allowing them to solicit funds from a variety of sources, local and international. ${ }^{85}$ Despite the permissive regulatory environment, CSOs in both countries face significant hurdles in their efforts to ensure sustainable funding.

In South Africa, CSOs are entitled to fundraise with very little government interference. With the exception of anti-terrorism laws that prohibit taking money known to arise from terrorist activities, organizations are free to solicit funds from individuals, foreign entities, businesses, state funding bodies and other sources. However, an open and permissive funding environment has been no guarantee of the availability of funds in South Africa.

With the end of apartheid, a number of international funders reduced their funding activities in the country or redirected their funding away from CSOs and towards the state. ${ }^{86}$ Funding to South African CSOs has continued to decrease over the last two decades and a number of longstanding organizations have struggled to attract adequate funds to continue their operations. ${ }^{87}$ As a middle-income country, South Africa also no longer meets the requirements for many northern funding programmes. The UK Department for International Development, for example, withdrew as a development donor to South Africa in 2014, while other international funders reduced their South African grants. ${ }^{88}$ With these reductions in international funding, many CSOs looked to domestic and state funding. ${ }^{89}$ Domestic sources of funding, however, have been insufficient to fill the gap left by international donors. In the late 1990s, the state established two funding entities to facilitate local and government funding to CSOs. However, institutional incompetence and corruption in both entities has threatened the financial wellbeing of CSOs, rather than ensuring their sustainability.

The National Development Agency (NDA) was established under the 1998 National Development Agency Act, with the aim of "promoting an appropriate and sustainable partnership between the government and civil society organizations to eradicate poverty and its causes".$^{90}$ The act states that the NDA must "act as a conduit for funding from the Government of the Republic, foreign governments and other national and international donors for development

85 Constraints on international sources of funds have been a major target in repressive CSO laws in a number of countries. See K Dupuy, J Ron and A Prakash "Hands off my regime! Governments' restrictions on foreign aid to non-governmental organizations in poor and middle-income countries" (2016) 84 World Development 299.

86 Habib State of the Nation, above at note 14 at 234.

87 R Davis "The great NGO funding crisis" (23 July 2012) Daily Maverick.

88 L Stuart "The end of UK aid: Is South Africa ready?" (10 July 2013) NGO Pulse, available at: <http://www.ngopulse.org/node/32443> (last accessed 22 December 2021).

89 Stuart "The South African nonprofit sector", above at note 80.

90 National Development Agency Act 108 of 1998, preamble. 
work to be carried out by civil society organisations". ${ }^{91}$ While the NDA was established to facilitate CSOs and to assist with the generation and distribution of funding, it has been plagued by corruption and incompetence. In its first year, it distributed less than 10 per cent of its budget. Investigations into NDA spending found that the NDA spent more money on marketing and building the profile of board members than it distributed to CSOs. ${ }^{92}$ The NDA's failure to distribute funds adequately resulted in significant decreases to its budget from both the state and outside funders.

The second of South Africa's national funding agencies has also failed to fulfil adequately its mandate of distributing funds to CSOs. The Lotteries Act 1997 created the National Lotteries Distribution Trust Fund (NLDTF) to receive money from the national lottery. In its 2008 report, the NLDTF set itself the objective of distributing 85 per cent of its allocated funds, but made less than 50 per cent available for distribution (of which a lesser percentage was actually distributed). ${ }^{93}$ It has also frequently failed to make timely decisions on grant applications or to deliver funds once it had awarded a grant. ${ }^{94}$ Since the NLDTF is one of the few funders funding operating costs, a number of organizations depend heavily on it, and these delays have radically hampered their ability to continue operating. In respect of both the NDA and the NLDTF, a 2011 report found "that these agencies are overly bureaucratic, and that agency technocrats are playing an increasing role in defining and influencing approaches to social development". ${ }^{95}$ In other words, the government has been using its funding vehicles to shape and control CSO activities.

Ethiopia has also struggled to encourage and establish domestic sources of funding for CSOs. Despite regulatory requirements that local CSOs secure 90 per cent of their funds from domestic sources under the CSP, few Ethiopian individuals or businesses stepped up to replace foreign funds with their own donations. ${ }^{96}$ This was in large part due to the fact that the state has historically demonized the CSO sector and associated the sector with opposition politics. ${ }^{97}$ As a result, the state not only limited the capacity of CSOs to attract

91 Id, sec 4(1).

92 R 90 million was reportedly paid to the NDA's finance director. In the following year, the auditor general found that an individual clerk had stolen nearly $R 9$ million. See: "National Development Agency" (The South African Institute for Advancement factsheet), available at: <http://www.inyathelo.org.za/fpa/NDAFactSheet.pdf> (last accessed 14 December 2021).

93 S Benjamin-Lebert and T Lebert "Meeting their mandates? The research report on the National Lottery Distribution Trust Fund (NLDTF) and the National Development Agency (NDA)" (2011, Funding Practice Alliance) at 83.

94 Id at 111.

95 Id, Foreword.

96 Dupuy, Ron and Prakash "Who survived?", above at note 29 at 441.

97 Ibid. They also note, however, that Ethiopians make significant charitable donations, but that these donations are made, for the most part, through religious charities and organizations. 
foreign funds but may also have effectively limited their ability to attract local funding.

The CSOP removed all funding restrictions and CSOs are now free to solicit funds from any source. South Africa's experience suggests, however, that developing and encouraging domestic sources of funding is crucial if CSOs are not going to be subject to the shifting priorities and interests of international donors in times of political and economic change. The CSOP does not directly address the question of how to encourage domestic CSO funding, ${ }^{98}$ but it does take a step in this direction by creating the Civil Society Fund (the Fund). The Fund comprises money and property acquired through the dissolution of CSOs (including property taken from CSOs dissolved under the CSP) along with an unspecified state subsidy. Questions about the ethics of using misappropriated funds from the CSO sector to fund the CSO sector aside, experience in South Africa suggests that state-administered funds are susceptible to misuse and might be deployed to influence CSO activities and agendas. In addition, the Fund is to be administered by the Agency, ${ }^{99}$ an entity that is already short on competence to meet its mandate and that lacks CSO trust and support, as discussed above.

While CSOs are free to solicit funds in Ethiopia, the CSOP seems to go too far in regulating how CSOs can spend their funds. It is not unusual for legislation to specify that CSOs must spend their earnings and funding in pursuit of their identified non-profit activities. However, Ethiopian regulation exerts a greater degree of control over the expenditure of CSOs. As discussed, under the CSP, CSOs were obliged to allocate not more than 30 per cent of their expenditure to "administrative activities". ${ }^{100}$ This so-called 70:30 regulation was designed "as a mechanism to ensure that the majority of project funding reaches the intended beneficiaries rather than going toward excessive overhead costs". ${ }^{101}$ However, "administrative costs" were defined extremely broadly and included a wide range of costs that would normally be considered part of programme implementation costs, such as training, networking and research costs. Surprisingly, the CSOP does not abandon this restriction, rather it has decreased to 20 per cent the amount that may be allocated to administrative costs. ${ }^{102}$ The CSOP does, however, limit the classification of administrative costs, which no longer include research, networking, training and other programme costs. Nevertheless, this continued state oversight of CSO expenditure may unreasonably and unnecessary limit the freedoms of CSOs and

This article does not discuss the role of tax law in encouraging and incentivizing donations to civil society. Both South Africa and Ethiopia do create incentives through their tax law but the question of whether these measures meaningfully encourage donations (especially in lower-income countries) is beyond the scope of this article.

99 CSOP, art 6(18).

100 CSP, art 88.

101 Brechenmacher "Civil society under assault", above at note 1 at 79.

102 CSOP, art 63(2). 
affect their ability to secure funds. This may have a particularly detrimental impact on smaller CSOs and on organizations in the early years of operation.

A permissive regulatory funding environment is essential to ensuring that CSOs that depend on funding have the freedom to operate and to undertake their activities. The CSOP does away with funding constraints and connected governmental controls over CSO activities but, in both Ethiopia and South Africa, more than regulation is needed to create a sustainable funding environment for CSOs. Both countries need to grow domestic sources of funding and to ensure transparency and accountability by funders, especially for state funding bodies. The experience of South African CSOs suggests that a lack of domestic funding, institutional incompetence and corruption can undermine CSOs' financial stability and sustainability. In Ethiopia, sustained government antagonism towards civil society has had a chilling effect on domestic funding. Building public confidence in CSOs and efforts to encourage public funding need to accompany regulatory reform.

\section{SELF-REGULATION}

Self-regulation is often seen as an important response to state, funder and public concerns about the accountability and capability of the CSO sector. It is also viewed as a crucial component of building public trust. ${ }^{103}$ Over recent decades, a number of national, regional and international self-regulation initiatives have been launched and a growing number of states have begun to facilitate some degree of CSO self-regulation within their regulatory framework. While these efforts and measures have had varying degree of success, self-regulation is often still seen as an important component of an enabling regulatory environment for CSOs. ${ }^{104}$

In Ethiopia, the adoption of the CSOP marks a significant move away from a system of exclusive state control towards greater self-regulation by the sector. The CSOP does this by establishing the Civil Society Organisations Council (the Council), the tasks of which include enacting a code of conduct. ${ }^{105}$ The new law advances "a regulatory system led by a voluntary code of conduct adopted by Organizations through the Council to govern themselves". ${ }^{106}$ The Council is to be established by CSOs, but convened by the (already overburdened) Agency. The law seems to envision a CSO-led entity, but one established with the assistance of the state. Once established, the Council's primary tasks will be to: enact

103 O Breen, A Dunn and M Sidel Regulatory Waves: Comparative Perspectives on State Regulation and Self-Regulation Policies in the Nonprofit Sector (2016, Cambridge University Press); D Guénéheux and A Bottomley "Accountability for civil society by civil society: A guide to self-regulation initiatives” (2013, CIVICUS); S Warren and R Lloyd "Civil society selfregulation" (The Global Picture briefing paper 119, 2009).

104 M Gugerty "The emergence of nonprofit self-regulation in Africa" (2010) 6 Nonprofit and Voluntary Sector Quarterly 39.

105 CSOP, art 84(5)(a).

106 Id, art 2(14). 
the code of conduct for the sector, and devise enforcement mechanisms in consultation with the Agency, donors and other stakeholders; advise the Agency on the registration and administration of organizations; and represent and coordinate the civil society sector. ${ }^{107}$

The shift to a partially self-regulatory system in Ethiopia is significant. It indicates a greater degree of trust by the state in the sector and creates the possibility for greater flexibility and systems of accountability suited to the needs and circumstances of a wide variety of organizations. While self-regulation means, by definition, a system that is not fully mandated by government regulation, ${ }^{108}$ the South African experience suggests that self-regulation should not necessarily mean a "hands-off" approach by the state. ${ }^{109}$

Under the South African NPO Act, there is very little that regulates the day-to-day internal governance of civil society organizations. While entities established as non-profit companies are subject to the stricter and more prescriptive obligations outlined in the Companies Act, the NPO Act imposes almost no requirements on the governance structures of CSOs, the content of their founding documents ${ }^{110}$ or how they should engage with members and beneficiaries. The regulatory framework is not prescriptive with regard to day-to-day management, as it was drafted with a view to encouraging selfregulation. It does this, in part, by making the Directorate responsible for ensuring "that the standard of governance within nonprofit organizations is maintained and improved" 111 and for developing model documents (including model constitutions) and codes of good practice. ${ }^{112}$ The Directorate has fulfilled this mandate by developing codes of good practice, which are available in a number of languages. ${ }^{113}$

The Directorate has published codes relating to leadership and management, fundraising and resource mobilization, and the roles and responsibilities of donors and sponsors. ${ }^{114}$ The codes emphasize the role of CSOs as partners of the state and private sector "in the upliftment and care for South Africa's communities and environments". ${ }^{115}$ They list a number of operating principles and suggest duties of a CSO's governing board and managers. While the codes outline some useful basic practices (such as regular

107 Id, art 85(5)(c).

108 Warren and Lloyd "Civil society self-regulation", above at note 103 at 2.

109 A "hands-off" approach to CSO regulation has been adopted in Germany and The Netherlands. See C Gildert "Regulating political activity of civil society" (2018, CIVICUS and ICCL) at 10-11.

110 Beyond the limited requirements set out in NPO Act, sec 12(2) and (3).

111 Id, sec 5(b)(ii).

112 Id, sec 6.

113 These are available at: <http://www.saifundraising.org.za/wp-content/uploads /2017/06/Model-Codes-of-Good-Practice.pdf> (last accessed 22 December 2021).

114 "Codes of good practice for South African non-profit organisations" (2001, NPO Directorate).

115 Id, "Purpose of the codes". 
reviews of managers and turnover of board members) they provide few detailed standards of conduct. All of them are, necessarily, broad and vague in their attempts to address the governance needs of a vast array of organizations. The Directorate also drafted a code for funders, pointing to the need for funders also to be transparent and accountable in their activities and practices.

As a government agency, the Directorate does not comprise civil society representatives. In 2012, a group of CSOs adopted the Independent Code of Good Governance for Non-profit Organizations in South Africa (Independent Code). ${ }^{116}$ Like the Directorate's code, the Independent Code sets out broad principles and guidelines that can be adopted by a wide range of organizations. It endeavours to give more substantive content to the values it argues all CSOs should adopt, and to spell out some of the ways in which organizations of different sizes can apply rules of effective governance.

However, neither the Directorate's codes nor the Independent Code provide for any mechanisms to assist organizations in incorporating the codes into their daily practice or implementing them in their engagements with the state, donors or other CSOs. The NPO Act did not create any government responsibility for implementing the codes and the state provides no support to CSOs in this regard. The codes amount to little more than a set of suggestions. In 2009, the Department of Social Development conducted a study into the codes and found that 82 per cent of CSOs were unaware of their existence. ${ }^{117}$

Self-regulation of internal governance is important because it allows CSOs to make informed choices about how best to govern themselves and ensure their independence. The South African government has no right to participate in or be notified of any meetings and generally cannot interfere in the internal governance of an organization. However, a lack of oversight and assistance in implementing self-regulatory standards means that these organizations can operate in a manner that is inconsistent with sustainable managerial practices, to the detriment of organizations, members and beneficiaries.

South Africa can learn from Ethiopia in this regard, as the CSOP does make greater provision for state support to CSOs in the implementation of selfregulatory systems. The Agency is tasked with supporting self-regulation and administration by the sector and article 6(4) of the CSOP requires that the Agency "provide the necessary support to organizations to enable them to have systems of internal governance and self-regulation that ensure transparency and accountability and to work together towards implementation of the same". While this suggests that Ethiopia may avoid the problem South Africa

116 A copy of the code and more information about it are available at: <www.governance. org.za> (last accessed 14 December 2021).

117 "The Code of Good Practice" (DGMT), available at: <https://dgmt-commons.co. za/establishing-an-ngo-legal-compliance-and-registration/what-is-the-role-of-the-npodirectorate/the-code-of-good-practise/> (last accessed 14 December 2021). 
now faces of too much hands-off governance by the state, two challenges remain. The first relates to the Agency's capacity and resources to carry out its role of supporting self-regulation. Agency staff and CSOs already report that the Agency lacks the capacity and skills to implement its existing legal obligations. ${ }^{118}$ A second, related problem is that a self-regulatory system that is administered by the state may be quickly co-opted by the state for its own purposes (to police CSOs) or may simply amount to a committee-approved version of state regulation.

There is an obvious tension in determining what the state's role should be in the governance of CSOs. Given the role that the state has played in undermining and reducing the CSO sector over the past decade, it is important for the Ethiopian government to play a role in supporting and rebuilding that sector, including through facilitating and funding self-governance by the sector. However, while Ethiopia has undergone significant political changes in the past year, the ruling party and most of the government's personnel remain the same and it is unclear whether the government can (or will) play a supportive but non-intrusive role.

Effective self-regulation by the CSO sector can be important because it can discourage and prevent inappropriate and excessive government intervention. ${ }^{119}$ Failed self-regulation in Ethiopia may be used as an excuse by the government to resume its previous oppressive practices. However, in a country in which the civil society sector has been substantially weakened, and collaboration and networking have been discouraged, there may be a need for the state to play a role in ensuring the success of self-regulatory systems. For both Ethiopia and South Africa, a balance is needed between hands-off regulation and state support. It is not clear that either the Ethiopian Agency or the South African Directorate, the entities tasked with facilitating selfregulation, have the competence or capacity (or, in South Africa's case, the mandate) to assist in realizing an effective self-regulatory system.

\section{CSO-STATE RELATIONSHIPS}

The civil society sector is often thought of, first and foremost, as nongovernmental and largely insulated from the state. ${ }^{120}$ The global rise of restrictive regulation that specifically seeks to limit or constrain the existence, work or funding of CSOs has, however, revealed the vulnerability of this sector to state interference and the role of states in shaping the "emergence, activity and survival" of CSOs. ${ }^{121}$ Organizational ecology scholars have argued that CSOs are often thought of as sitting between the state, the market and the

118 Interview with Agency employees, 31 October 2018; interview with CSO employee, The Netherlands, 20 September 2018; interview with CSO employee, Ethiopia, 3 August 2018.

119 Warren and Lloyd "Civil society self-regulation", above at note 103 at 4.

120 Dupuy, Ron and Prakash "Who survived?", above at note 29 at 420.

121 Ibid. See also Toepler and Salamon "The influence", above at note 2. 
family, in a sphere of their own. ${ }^{122}$ These scholars, however, have sought to demonstrate that organizations are dependent on and vulnerable to factors in the external environment. ${ }^{123}$ This literature has emphasized the role of funders in shaping these organizations, sometimes (and especially where foreign aid is the primary source of funding) for the worse, under the banner of resource dependency theory. ${ }^{124}$ For Dupuy et al, however, none of this literature adequately considers states' power and influence. States "enact and enforce the rules under which NGOs emerge, operate, use resources, and survive; govern NGOs physical access to territories and populations; and grant NGOs permission to operate in specific issue areas". ${ }^{25}$ A comparison of Ethiopia and South Africa suggests that it is not only through the creation and enforcement of rules that states shape and influence the civil society sector. State perceptions of CSOs and the relationship between CSOs and state employees can also be enormously significant for how and whether CSOs are able to operate and raise funds. ${ }^{126}$ What a comparison between these countries reveals, however, is that enabling regulation is not enough to ensure good state-CSO relationships and that sometimes state-CSO collaboration can happen even in repressive regulatory environments.

In South Africa, one of the primary aims of the NPO Act is to secure good relations between non-profit organisations and the state. Chapter 2 of the act includes a section titled "State's responsibility to nonprofit organisations". The section provides: "[w]ithin the limits prescribed by law, every organ of state must determine and co-ordinate the implementation of its policies and measures in a manner designed to promote, support and enhance the capacity of nonprofit organisations to perform their functions". ${ }^{127}$ Ricardo Wyngaard argues that "this section is unprecedented within the international context and captures the state's commitment to promote, support, and enhance the capacity of nonprofit organizations to perform their functions". ${ }^{128}$

Despite the fact that South African law is unique in emphasizing the importance of state-CSO relationships and in specifically providing for measures to enhance and facilitate those relationships, CSOs in South Africa face a general erosion of the rule of law and a souring of state attitudes towards the CSO sector. ${ }^{129}$ This threatens the operation and effectiveness of CSOs

122 Hossain et al "What does closing civic space", above at note 3 at 17.

123 A Hillman, M Withers and B Collins "Resource dependence theory: A review" (2009) 35 Journal of Management 1404.

124 Ibid.

125 Dupuy, Ron and Prakash "Who survived?", above at note 29 at 422.

126 Buyse "Squeezing civic space", above at note 1 at 969.

127 NPO Act, sec 3.

128 R Wyngaard "The South African NPO crisis: Time to join hands" (2013) 15 International Journal for Not-for-Profit Law 5 at 6.

129 S Gastrow "Civil society landscape" (2013), available at: <http://www.ngopulse.org/no de/32440> (last accessed 22 December 2021). 
that are critical of the state but also suggests the risk that current laws might be amended to create a less favourable environment. ${ }^{130}$ There is some evidence to suggest that a number of state bodies (and some of the entities established by the state to support non-profit organisations) see CSOs merely as service providers or "even worse, as a nuisance". ${ }^{131}$ In recent years, senior government officials have publicly adopted a critical stance towards the nonprofit sector. In 2013, the basic education minister accused Equal Education, a national NGO working on education, advocacy and litigation, of being "a group of white adults organizing black African children with half-truths", describing them as "opportunistic, patronising and simply dishonest to say the least". ${ }^{132}$ In 2016, the state security minister accused CSOs of collaborating with foreign forces to destabilize the country and that "government would not be shy in dealing with them". ${ }^{133}$ CIVICUS has found that the state has been responsible for intimidating and persecuting civil society activists for exercising their rights. It reports that "human rights defenders, especially those working on sensitive land and housing rights issues, continue to face severe intimidation and harassment, including assassination". ${ }^{134}$

In Ethiopia, the state has clearly demonstrated a negative perception of CSOs in the last decade. Beyond propaganda campaigns that demonize the sector as self-serving and politically compromised, CSOs argue that the state sees them as little more than service providers, filling in gaps in the state's rollout of goods and services. ${ }^{135}$ As a result, CSOs have been excluded from policymaking and governance matters. Negative state perceptions of CSOs have meant that they have been hindered in their attempts to raise funds, in complying with bureaucratic requirements and in the roll-out of their work programmes. ${ }^{136}$ Negative state perceptions have infected wider society, discouraging domestic sources of funding from growing and hindering collaboration between CSOs and businesses. ${ }^{137}$ In some sectors, the state's negative perception of the CSO sector has extended to harassment and the arbitrary arrest of activists, not only undermining the ability of CSOs to do their work but also rendering their work life-threatening. ${ }^{138}$

130 R Davis "Draft Lotteries Amendment Bill: Gambling with the future of SA civil society?" (20 June 2013) Daily Maverick.

131 Gastrow "Civil society landscape", above at note 129.

132 Davis "Draft Lotteries Amendment Bill", above at note 130.

133 T Gqirana "Some NGOs are security agents of foreign forces: Mahlobo" (26 April 2016) news24.

134 "Joint submission", above at note 81, para 3.1.

135 Interview with CSO employee, Ethiopia, 1 August 2018; interview with CSO employee, Ethiopia, 2 August 2018.

136 Broeckhoven et al "CSOs in sustainable development", above at note 27.

137 Dupuy, Ron and Prakash "Who survived?", above at note 29. See also Yeshanew "CSO law in Ethiopia", above at note 45.

138 "Sounding the horn: Ethiopia's civil society law threatens human rights defenders" (report of the Center for International Human Rights, Northwestern University school of Law, November 2009) at 7. 
While Ethiopia provides an example of the collapse of CSO-state relationships, there are indications that CSOs have managed to establish cooperative and mutually beneficial relationships with some government bodies. CSOs have been given various kinds of support and help from government bodies, including office space and other infrastructural support. ${ }^{139}$ Local government bodies have sometimes endeavoured to bring CSOs into communities and to encourage community support and cooperation with those organizations. While the majority of CSOs reported that the state has been interventionist, obstructive and sometimes violent in its dealings with CSOs, some cooperative and beneficial relationships have been able to emerge even in conditions of extreme regulatory suppression of CSOs, particularly at the local level.

The preamble to Ethiopia's CSOP recognizes the importance of CSOs to transparent, accountable and participatory government affairs, and states that an enabling environment for CSOs is critical to the democratization and development of the country. These statements suggest the recognition of the important relationship between the work of CSOs and good governance, but the law includes no provisions directed at addressing the historical breach between the state and civil society. ${ }^{140}$ While these provisions are not common in civil society regulation (and not necessarily effective, as seen in the case of South Africa), they might be especially important in the Ethiopian context, where regulatory change has not been accompanied by governmental, institutional or personnel change. There is little to guide CSOs seeking to engage with the state and less to encourage state bodies to work with and in support of CSOs.

In South Africa, despite an open regulatory environment, state officials have been openly antagonistic and even violent towards CSOs. In Ethiopia, in a previously closed regulatory environment, good working relationships were sometimes able to emerge between some sectors of government and some CSOs. While South Africa's law encourages cooperation, Ethiopia's old law actually compelled cooperation (although often in problematic and interventionist ways). It is important not to overstate the extent to which CSOs in Ethiopia have been able to work well with government, nor to imply that CSOs in South Africa have only had negative relationships with government entities. What is clear, however, is that the attitudes and views of state officials can have a significant impact on the work and effectiveness of CSOs. While simply stating that the state must work with CSOs (as South African law does) is no guarantee of cooperative relationships, legal mechanisms that do

139 See the discussion of positive collaboration between CSOs and local government in AT Ariti, J van Vliet and P Verburg "What restrains Ethiopian NGOs to participate in the development of policies for natural resource management?" (2018) 89 Environmental Science $\&$ Policy 292 at 295.

140 With the exception of CSOP, art 5(6), which calls on the Agency to "put in place mechanisms to strengthen positive working relations between organizations and the government". 
compel CSOs and state bodies to cooperate and collaborate may be beneficial. Regulating attitudes is not possible, but facilitating greater cooperation through regulatory mechanisms, among other things, is. Ethiopia's CSOP recognizes the importance of CSOs to the work of government, but whether this will result in greater openness, collaboration and support between government entities and the CSO sector is yet to be seen.

\section{CONCLUSION: CIVIL SOCIETY AND THE LAW}

A few months into the author's empirical research in Ethiopia, it became apparent that all the CSO employees and representatives interviewed believed that the CSO sector needed to be regulated by the state. While recognizing the importance of sound civil society regulation, this ongoing faith in government regulation was surprising, since CSOs were then still subject to the CSP, had all suffered under its provisions and believed that the state was untrustworthy, had a negative perception of the civil society sector and was acting against their interests. The reasons interviewees gave for the need for regulation are similar to the reasons one finds in the literature. Regulation is seen as an effective means of ensuring that CSOs are transparent and accountable ${ }^{141}$ regulation prevents abuses and the growth of "briefcase" CSOs, ${ }^{142}$ and regulation improves state and public perceptions of CSOs, which is necessary to ensure a sustainable and active sector. ${ }^{143}$ Rutzen and Moore have argued:

"An enabling legal framework is certainly no guarantee of a vibrant civil society, and a disabling or restrictive legal framework is not necessarily an insurmountable barrier for civil society engagement and participation in public affairs. Nonetheless, the legal framework plays a pivotal role and an overall supportive legal framework can be considered a necessary, but not sufficient, condition for the development of a strong and sustainable civil society sector." 144

Taken together, the experiences of Ethiopian and South African CSOs suggest that, while repressive CSO legislation can do significant harm to the sector, progressive CSO legislation is no guarantee of a thriving or sustainable sector. However, the "hands-off" regulatory approaches that have been adopted in some northern countries may not be well suited to building a thriving civil society sector in South Africa or Ethiopia, where the state has an important

141 Roberts "Closing civic space", above at note 33 at 19.

142 Quoted in Dupuy, Ron and Prakash "Who survived?", above at note 29 at 433.

143 One aspect of this is the idea that civic space has not shrunk but has changed, and that the emergence of digital spaces has opened up, particularly for conservative and right-wing groups that sometimes use such spaces to incite violence and hatred. See Hossain et al "What does closing civic space mean", above at note 3 at 14 .

144 Rutzen and Moore The Role of Legal Reform, above at note 6 at 6. 
role to play in building domestic funding and in addressing some of the harm caused by its own policies and attitudes.

What is clear from both case studies is that, when the state creates institutions or agencies tasked with administering or facilitating CSOs, the failures of these institutions and agencies can have far-reaching negative impacts on the sector. This is a problem of implementation, ${ }^{145}$ but it is also more than that. These institutions both enact and reflect the state's attitudes towards CSOs. The experiences of CSOs dealing with the Agency in Ethiopia suggest that these institutions are not just implementers of law, but interpreters of law. In the case of South Africa, it is hard to know how things would have been different had the law not established the Directorate, the NDA or the Lotteries Fund, but it is clear that incompetence and corruption in these bodies delayed the establishment and work of CSOs and did little to ensure their financial sustainability.

In both Ethiopia and South Africa, there is a tension in the role of the state and law in advancing the interests of CSOs. On the one hand, the state in both countries has proved itself unwilling or unable to work with and promote civil society; interventionist policies and threatening practices mean in both cases that the state is not easily trusted with the interests of CSOs. On the other hand, there is a clear and important role for the state to play, both in addressing the poor perception of CSOs it has engendered and in facilitating and providing the resources for a strong and independent civil sector to grow. Law that achieves a balance between ensuring an accountable CSO sector and creating an enabling environment for CSOs to work and thrive, is a crucial part of this, but strong institutions and positive state perceptions are essential for that law to work.

\section{CONFLICTS OF INTEREST}

None 